of the dioxide ${ }^{8}$ there is little left in this restricted field as water vapor covers the whole range of terrestrial radiation very effectively. Abbot and Fowle, after very elaborate studies and observations and a review of the available data on the subject, sum up as follows:

It therefore does not appear possible that the presence or absence, or increase or decrease, of the carbonic acid contents of the air are likely to appreciably influence the temperature of the earth's surface. 9

There is no evidence showing that the temperatures of the depths of the Atlantic ocean are affected by the salter waters of the Mediterranean Sea. The temperatures of the depths of the Mediterranean Sea are controlled by that of the Atlantic at the depth of the sill of the Straits of Gibraltar, over which there is an inflow into the Mediterranean to replace evaporation and surface outflow less about 30 inches of precipitation. The temperatures of the depths of the Atlantic are controlled by those of polar waters. ${ }^{10}$

The area of the Mediterranean and tributary seas is about 1,149,000 square miles; of polar oceans down to the parallels of 60 degrees about $187,890,000$ square miles. The relative influence of Mediterranean outflow upon abysmal depths of the Atlantic, according to the conclusions of Professors Chamberlin and Salisbury, is probably negligible.

$$
\begin{aligned}
& \text { San Francisco, Calif., } \\
& \text { March 18, } 1918
\end{aligned}
$$

\section{TRANSLATIONS MADE ACCESSIBLE}

I READ with much interest in the last number of your paper a communication from Mr. Burling regarding translations of foreign literature. If anything is contemplated in the way of a central bureau we would submit for your information that the Technical Section of the Canadian Pulp and Paper Association and the

8 Chamberlain and Salisbury, "Geology," Vol. II., p. 672.

9 Ann. Astrophysical Obs. Smithsonian Institution, Vol. II., pp. 172-73.

10 Chamberlin and Salisbury, "Geology," Vol. II., $658-60$.
Technical Association of the Pulp and Paper Industry (U. S.) through their committees on Abstracts are publishing each week in Paper, New York, and the Pulp and Paper Magazine of Canada, Montreal, abstracts of the literature relating to this industry.

These abstracts include reviews of articles appearing in American, Canadian, British and Scandinavian Journals relating to pulp and paper-making, lumber and forestry and will in time embrace those in other languages when such periodicals are again available. The committees are ready to loan original copies of the periodicals reviewed and to supply translations where they are desired.

You are probably aware that Industrial Management of New York has a similar department relating to engineering and similar topics and that their organization is also prepared to supply translations of such articles.

$$
\begin{gathered}
\text { J. N. STEPHENSON, } \\
\text { Chairman Committee on Abstracts, } \\
\text { Technical Section, C.P.\& P.A. }
\end{gathered}
$$

\section{A NEW CALENDAR}

ON April 16 Hon. J. M. C. Smith, of Michigan, introduced into Congress, at the request of Mr. C. W. Bennett of Coldwater, Michigan, a bill providing:

That beginning with the year nineteen hundred and twenty each year shall have thirteen months of four weeks, or twenty-eight days each, the added month to be ealled Sol (from solstice) and to follow June.

Sec. 2. That Monday shall be the first day of the week and the first, eighth, fifteenth and twentysecond days of every month; the other days of the week to follow in rotation by number, making Sunday the seventh day of the week and the seventh, fourteenth, twenty-first and twenty-eighth days of every month.

Sec. 3. That the day following the last day of December, nineteen hundred and nineteen, and the last day of December in each subsequent year shall be called New Year Day. It shall be legal holiday, the first day of the new or following year, but not a part of January.

Sec. 4. That in the year nineteen hundred and twenty and every fourth year thereafter shall be an extra day called Leap Day, to be placed between June and Sol, but not to be a part of either 